UDC 811.161.2-35

DOI https://doi.org/10.24919/2308-4863/45-2-17

\author{
Liliia SOBOL, \\ orcid.org/0000-0001-7233-5756 \\ Candidate of Philological Sciences, \\ Associate Professor at the Department of English Language Practice \\ Drohobych Ivan Franko State Pedagogical University \\ (Drohobych, Lviv region,Ukraine) lilia.sobol@gmail.com
}

\title{
ENHANCEMENT OF UKRAINIAN GRAPHICS AND DEVELOPMENT OF ORTHOGRAPHY
}

The article analyses an issue that is in the focus of attention in the present day: the genesis of establishment and development of Ukrainian graphics and orthography. The author outlines the interconnection existing between the abovementioned segments of linguistics and emphasises that rules and standards of the latter are caused by the defining properties of the former. The article also examines Ukrainian linguography as a realm of academic research wherein theoretical aspects of reflection of the vocal language in writing are reflected, considering the importance of taking the linguistic and cultural factor into account. Well in tune with this is the objective of the present research which is to analyse the establishment and development of graphic characters of Ukrainian language culture.

The principal statement substantiates the necessity to highlight three periods in the history of Ukrainian linguography: the Old Rus period (from the $10^{\text {th }}$ to the $14^{\text {th }}$ century), the Old Ukrainian period (final quarter of the $14^{\text {th }}$ century to $18^{\text {th }}$ century), and the New Ukrainian period (lasting from the $19^{\text {th }}$ to early $21^{\text {st }}$ century), whereby the unique nature of each of these periods is described in detail. Characteristics defining the Old Rus period include distinctive interconnection with the graphics of Old Church Slavonic language as well as the existence of such varieties of script as ustav and halfustav. It has been noted that dividing the Old Ukrainian period (1 $15^{\text {th }}$ to $16^{\text {th }}$ century) into two sub-stages is (I) due to spelling reforms implemented by Patriarch Euthymius of Tarnovo; and (II) due to to the development of book printing and a work by Meletii Smotrytskyi which stipulated for the elimination of the hitherto existent orthographic chaos; due to the appearance and rapid development of skoropys/quickwrite which helped the script enter the realm of business correspondence and everyday life; and due to the expansion of the composition and functionality of graphemics, as it then developed peculiarly Ukrainian characteristics. The article pays particular attention to the Stage III: the New Ukrainian period which is the most dramatic era, marked by numerous bans imposed upon Ukrainian writing, by attempts to russify and latinise it, but first and foremost by steadfast struggle of Ukrainians from both Dnipro River Region and from Galicia for the cause of implementation of Ukrainian graphics, linguography, and linguoculture in general. Conclusions assert that the Ukrainian system of spelling has come a long way from its emergence and development to its firm establishment and implementation - all thanks to enormous effort put in by academic researchers and cultural activists of many generations of Ukrainians.

Key words: graphics, orthography, linguography, Ukrainian spelling system, Ukrainian linguistic culture.

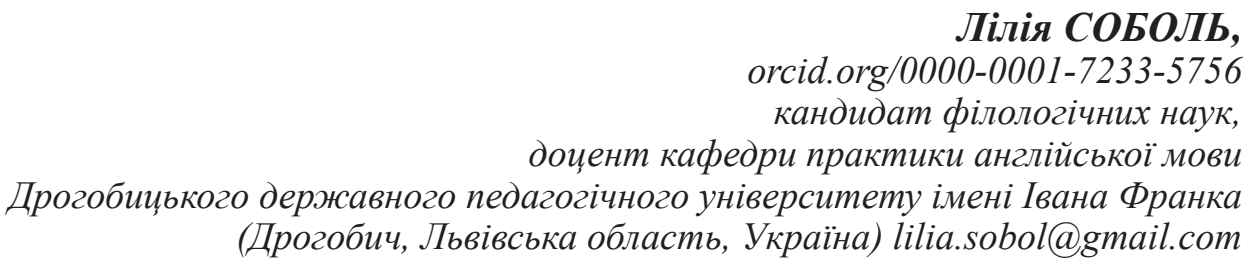

\section{УДОСКОНАЛЕННЯ УКРАЇНСЬКОЇ ГРАФІКИ ТА СТАНОВЛЕННЯ ОРФОГРАФІЇ}

У статті проаналізовано актуальну для сьогодення проблему становлення та розвитку української графіки та орфографіі. Наголошено на взаємопов'язаності ичих розділів мовознавчої науки та зумовленості правил і норм другої визначальними характеристиками першої. Ідеться також про українську лінгвографію як науку, що досліджує теоретичні аспекти відтворення звукової мови на письмі, і про вагомість урахування в просторі ї̈ проблематики лінгвокультурного чинника. Із зазначеним корелює мета розвідки - аналіз становлення й розвитку графічних знаків української лінгвокультури. У викладі основного матеріалу підтверджено слушність виокремлення в історії української лінгвографії загалом, графіки зокрема 3 етапів: давньоруського (X-XIV ст.), староукраїнського (ост. чв. XIV-XVIII cm.), новоукраїнського (XIX-поч. XXI cm.) та окреслено своєрідність кожного з них. До визначальних ознак давньоруського етапу віднесено виразну пов'язаність із графікою иерковнослов'янської мови, а також побутування таких різновидів письма, як устав і півустав. Заначено, щзо виокремлення 2 підетапів у староукраӥнському періоді (XV-XVI cm.) пов'язане: I - із правописними нововведеннями патріарха Свфимія Тирновського; II - з постанням книгодрукування та з працею Мелетія Смотрицького, яка детермінувала 
усунення тодішнього орфографічного хаосу; зі з'явою та широким використанням скоропису, котрий засвідчив проникнення письма в ділову й побутову сфери суспільства, розширення складу й функцій графеміки, вироблення ї̈ специфічно украӥнських рис. У статті найтрунтовніше проаналізовано ІІІ етап - новоукраїнський, найдраматичніший за своєю суттю: він позначений численними заборонами на украйнське письмо, спробами його русифікації й латинізації, та передусім - невтомною боротьбою надніпрянських і галицьких украӥнців за утвердження української графіки, лінгвографії, лінгвокультури загалом. У висновках стверджено, щзо українська правописна система пройшла непростий шлях становлення й розвитку і щзо ї̈ утвердження - изе результат великої праці діячів науки й культури багатьох поколінь українців.

Ключові слова: графіка, орфографія, лінгвографія, украӥнський правопис, графема, украӥнська лінгвокультура.

Problem Statement. The brand new polyfunctional pragmatically directed academic linguistic paradigm calls for an update of approaches to conventional linguistic objects. Such objects include, among others, the system of graphemes, letter-sounds, and alphabetic letters that constitute the foundation of present-day scripts, basic units of linguography and graphics. The perfect nature of present-day Ukrainian alphabet is viewed by the author first and foremost in its exquisite simplicity, in its ability to express a wide range of sounds using a relatively concise system of letters. It is clear to us today that the alphabet has been shaped as a result of an interaction of linguistic cultures of various nations, as well as owing to investigative work conducted by Ukrainian academic researchers and the creative activity of the entire nation, by and large. Today, however, the Ukrainian alphabet and orthography is likewise and once again attracting the attention of Ukrainians, as we are tracing partial changes in the alphabet and, as attempts are being made to enhance our orthography, we are faced by modern-day "alphabet wars" (dubbed so by Ivan Franko). Besides, new interpretation is also needed in order to comprehend the specifics of functioning of letter names and names of other elements of the graphic system; the peculiarities of lexicalisation of the said characters in the Ukrainian language space as well as in the discourse practice of Ukrainians; and the phenomenon of their semantisation. The metalanguage of linguography and graphics needs to be systematised and unified.

Analysis of Prior Researches. Academic heritage of Ukrainian linguists focusing on the analysis of the process of enhancement and development of Ukrainian graphics and the buildup of orthography includes works by the following Ukrainian linguists: Andrii Buriachok, Ivan Vykhovanets, Dmytro Danylchuk, Serhii Doroshenko, Svitlana Yermolenko, Vasyl Nimchuk, Ivan Ohiienko, Vasyl Simovych, Mykola Stepanenko, Iryna Farion, Nadiia Fihol, and Yurii Shevelov. The names of their academic researches per se testify to the fact that the discourse on Ukrainian spelling rules is indeed a pressing issue of the present day in our academic circles; take, for instance, A Word on Graphics and Spelling Rules as Elements of Ukrainian Culture: the History of the Letter $g(r)$ by Vasyl Nimchuk, Consistent and Gradual, not Revolutionary Changes authored by Svitlana Yermolenko, The All-Too-Non-Academic Enthusiasm on the Matter of Ukrainian Spelling Rules by Ivan Vykhovanets et al.

The Objective of the present academic research is to analyse the buildup and the development of graphic characters of Ukrainian linguistic culture.

Principal Narrative. Spelling rules are a system of regulations stipulating how a certain language is to be [presented in writing; it is a certain "written codification wherein such a system (or, to be more precise, its main peculiarities) are presented as a compendium of rules" (Danylchuk, 2013: 15). Serhii Doroshenko submits his own observations on the matter of specifics of formation of Ukrainian spelling rules, noting how the "practice of Ukrainian Spelling Rules does indeed prove that the rules of orthography are based upon the long-entrenched standards of modern-day orthoepy (correct pronunciation). Some of these are to be aimed at preventing erratic forms of spelling caused by a widespread irregular pronunciation of certain sounds or words. They will be of value to those speakers who have not yet mastered the skills of using the literary language" (Doroshenko, 2009: 228] that is, apparently, the harmony of interconnection between sounds and letters (signified by the term grapheme, or letter-sound) has been lost. This is what Tetiana Kosmeda is contemplating, too, as she emphasises that: "the Ukrainian language and its regulations call for a certain "reboot". The Russian aggression has manifested itself in the Ukrainian spelling rules, too and today, even Ukrainian secondary school pupils begin to realise this. Quite recently, a $5^{\text {th }}$ form student has asked me what is the justification behind the rule stipulating that, after labial consonants $(\boldsymbol{\sigma}, \boldsymbol{n}, \boldsymbol{\boldsymbol { \sigma }}, \boldsymbol{M}, \boldsymbol{\phi})$, hushing consonants $(\boldsymbol{H}, \boldsymbol{u}, \boldsymbol{u}, \boldsymbol{m})$, postdorsal/guttural consonants $(\boldsymbol{2}, \boldsymbol{\kappa}, \boldsymbol{x}, \boldsymbol{t})$, and $\boldsymbol{p} \mathrm{NO}$ soft sign $(\boldsymbol{b})$ is to be written? The schoolgirl was wondering, however one would even imagine that a soft sign might be placed at the end of words like cmen/step, Hiu/nich or uap/tsar? Indeed, how would one even think of that? It is good that the younger generation has a good grasp, a good feeling of their own language, the actual uniqueness 
of its grapheme system. There remains, however, the question and a quite reasonable one indeed why do the Rules for Ukrainian Spelling stipulate rules factoring in the influence of the Russian language, considering the correspondence or non-correspondence with the rules of Russian orthoepy; it is, after all, in Russian that we have the abovementioned words written with a soft sign, namely: cmenь, ночь, ияарь. Such rules are only needed by those speakers whose mother tongue is Russian but hardly by any Ukrainian-speaking person. Why, then, are such regulations being found in the Rules for Ukrainian Spelling even today, and why are they confusing native speakers of Ukrainian first and foremost, the younger ones who are highly pragmatic in their approach to everything, who desire motivation and wonder about the explanation of everything that surrounds them, including rules of orthography which, in their absolutely just opinion, are grossly outdated. They are calling for a "reboot" of Ukrainian language on the level of the system of its orthographic, orthoepic, lexical, semantic, grammar, style, and communicative regulations" (Kosmeda, 2016: 43).

Ukrainian linguists consider the history of Ukrainian Spelling Rules an incredibly unique case, as "there is hardly another nation on this planet whom alien rulers or political parties had mandated the manner in which the nation was to be using its own language" (Nimchuk, 1991: 5), and there is hardly another country upon which so many bans on the usage of its language and its graphics have been imposed a hindrance which, beyond any doubt, was also slowing down the process of development and systematisation of the regulations in the realms of orthography and linguography as theoretical disciplines.

Let us remind ourselves that researchers highlight at least three stages in the development of Ukrainian Spelling Rules as they characterise its changes, the slowing down, and the acceleration of its development, specifically: the Old Rus (from the $10^{\text {th }}$ to the $14^{\text {th }}$ centuries); the Old Ukrainian (final quarter of the $14^{\text {th }}$ century to the $18^{\text {th }}$ century) and New Ukrainian (from the $19^{\text {th }}$ century to the early $21^{\text {st }}$ century) (Nimchuk, 2004).

It is commonly well-known that, since the $10^{\text {th }}$ century, ancestors of Ukrainians had been using the Old Church Slavonic script (which was partially influenced by Bulgarian). Thus, the morphology and vocabulary of the Church Slavonic had remained unchanged for quite a long time in the environment of Eastern Slavs; the phonetics (pronunciation), however, was impacted by actual living dialects of Ukrainians and this, in turn, impacted the spelling and graphics, too (Bulakhovskyi, 1977: 221-222).

The church literature was considered to be sufficient to satisfy the aesthetic needs of the educated classes. It was, moreover, "ironclad", as prescribed by the "book culture of the time". One should, however, also state beyond any reasonable doubt that secular writing were, too, "under the conservative auspices of the clerical stratum whose authority and whose irrevocable rights with respect to every element of schooling was never questioned" (Bulakhovskyi, 1977: 222-223).That said, it was as early as from the $10^{\text {th }}$ to the $14^{\text {th }}$ century that Old Ukrainians had already been resorting to ustav, a variety of Ukrainian script which is characterised by clarity, symmetry, even width, length, and spaces inside letters (lines in ustav were straight and rounded). Words thus written included titlos which served as abbreviations. There were no spaces between the letters, though. A full stop was a full stop, and three dots were displayed as a triangle; four dots were situated in the shape of a diamond. These were punctuation elements used to segment the text. The punctuation signs were used when a scribe needed a break from writing (Lopushynskyi, 2009: 35). Thus the basics of Ukrainian linguography came into being, and its polygraphic standards.

Beginning with the $14^{\text {th }}$ century, as the scope of written language in everyday life expanded, there appeared the half-ustav script. This variety of writing was more lax and less strict in what concerned shapes and sizes of letters; the letters themselves were smaller, more inclined towards the right hand side, more elongated, and less sharp. The advent of this style of writing testifies to the fact that the society had undergone certain changes, and a brand new era had begun, and from that moment on, the heritage of the written language came to be used by the broad social masses. Soon, the half-ustav became immensely popular among copy-writers and printers alike (Hrytsenko, 2010: 13) and this, in turn, was an evidence of a progress achieved in the Ukrainian linguography and polygraphy.

The Old Ukrainian period is commonly divided into two sub-periods, specifically: 1) the period from the $15^{\text {th }}$ to the $16^{\text {th }}$ century, marked by the second wave of Bulgarian influence upon denominational script. Patriarch Euthymius of Tarnovo, teamed up with his allies, had put together a set of rules which became widespread quite soon. Then, Grammatika Slovenska (1596), a later work by Lavrentii Zyzanii partially reflected the regulations of the said orthographic changes (Nimchuk, 2004: 5). The Euthymius Rules of Spelling called for using a $\boldsymbol{b}$ (a soft sign) instead of $\boldsymbol{b}$ (a hard sign/back yer) at the end of the word. Thus, for instance, the ancient form and pronunciation of the Greek word AMEN (аминъ) came to be incorrectly pronounced as як аминь (aminy) that is, the $\boldsymbol{\mu}$ at the 
end of the word became soft like Italian $\boldsymbol{g n}$ or Spanish $\tilde{\boldsymbol{n}})$. In addition to this, there also appeared forms like твоа, святаа. $\boldsymbol{K}$ (the Big yus) replaced $\boldsymbol{b}, \boldsymbol{s , \boldsymbol { o }}$ and some other letters. (Farion, 2005: 17-18).

The second subperiod in the development of the Old Ukrainian Spelling began as soon as first printing houses were set up in Ukraine. The Euthymius spelling rules fell into disuse from that moment on since as Ivan Ohiienko rightly points out "its nonliving features become increasingly redundant" (Ohiienko, 1990: 4); this, in turn, was an evidence of the fact that the grapheme system was gradually becoming more unique, more "vivid".

The new Ukrainian Spelling Rules were thus put together by Meletii Smotrytskyi. His "Slavic Grammar" ("Грамматіки славєнскиА правилноє Сvнтагма") printed in 1619 legalised the usage of the letter $\boldsymbol{t} / \mathbf{g}$ (prior to that moment, $\boldsymbol{t} / \mathbf{g}$ was reflected as $\boldsymbol{\kappa} \boldsymbol{2} / \boldsymbol{k} \boldsymbol{h}$ in writing) (Nimchuk, 2004: 5). In the opinion of Vasyl Nimchuk, this "new letter had, from that moment on, become smoothly integrated into the Cyrillic alphabet and into the Ukrainian orthography. Its shape, however (particularly, its later printed letter variant) resembled $\boldsymbol{z} / \boldsymbol{h}$ too much. This issue, in conjunction with the fact that, in our alphabet, $\boldsymbol{r}$ immediately follows 2 , creates an illusion of the fact that the sounds to which the said letters correspond, are close (and they indeed are not). Had Meletii Smotrytskyi never introduced a special symbol of $\boldsymbol{t}$, this plosive consonant would have been still displayed/written as two letters, $\boldsymbol{\kappa} \boldsymbol{z}$ as is the case with

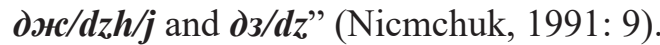

Meletii Smotrytskyi's grammar harmonised the rules for usage of those Church Slavonic characters which had no designated sound purpose, for instance: $\boldsymbol{o}, \boldsymbol{\epsilon}$ in singular, $\boldsymbol{w}, \boldsymbol{\epsilon}$ in plural, $\boldsymbol{A}$ at the end of the word and between other letters, iotated $\boldsymbol{a}$ at the beginning of letters, $\boldsymbol{b}$ (hard sign) in hard syllables and $\boldsymbol{b}$ (soft sign) in soft syllables, $\psi$ and 3 in loanwords from other languages. Besides, there had also been rules on how and when and why $\boldsymbol{u}$ or $\boldsymbol{b l}, \boldsymbol{r}$ or $\ddot{i}$ had to be written; these rules were blurry, dubious, and unclear. Due to the influence of Belarusian language, $\boldsymbol{r} \boldsymbol{m}$ was often confused with $e$ ( Simovych, 2005: 193).

It is only just to concur with Ivan Ohiienko who argues that Meletii Smotrytskyi's opus magnum "became the primary source of grammar reference for the entire Slavic people, for the ensuing 150 years at least" notwithstanding the fact that it was not particularly adjusted nor convenient to be used with the living Ukrainian language. Smotrytskyi's spelling rules "did not liberate the Ukrainian language from the foreign attire of its ancient script" (Ohiienko, 1990: 4). The editor of the new spelling rules is, however, to be credited with a major achievement which consisted in the fact that he had indeed managed to bring a certain order into the chaos of orthographic writing (as he codified rules stipulating which letters were to designate consonants and vowels, respectively; which punctuation symbols were to be used and how/why; how and when and why capital letters were to be used, and how one was to split a word in order to carry it over to the subsequent line) (Ohiienko, 1990: 4). This was a great progress in Ukrainian linguography; it also testified to the fact that the linguistic culture of the ancestors of Old Ukrainians did indeed undergo a serious development, as its system of graphemes impacted the development of other Slavic linguistic cultures, too.

In the 14th century, the half-ustav was supplemented by skoropys/'quickwrite'. This script was initially widespread in business correspondence, as its earliest samples were Cossack-produced documents. It is characterised by rounded letters and uninterrupted writing of words. The quickwritten letters were uneven: some of their elements became more complex; others were more simple; the letters became broader whereas elements connecting letters became hook-like. In addition to that, the writing became less proportional and letters were furnished with additional elements such as windings, curlings, lines, hooks and suchlike this was all due to the need to write faster and not in order to write letters more correctly at all. The advent of quickwrite is a peculiar evidence of the fact that the society had then undergone another wave of changes, as the written word became less of a luxurious item in use by the upper classes and more of an everyday commodity, used in quotidian matters, private affairs, business transactions, and international relations (Hrytsenko, 2010: 13; Lopushunskyi, 2009: 35-36). This was yet another step in the development of Ukrainian linguography which, in fact, kept developing afterwards, too, as the birth of quickwrite/skoropys prompted the emergence of cursive, i.e. the contemporary script used in manual writing. Manually written texts employed decorative lettering ( vyaz) in titles. At the same time, punctuation signs started to become more and more widespread Lopushunskyi, 2009: 35-36). The graphemics became more composite and more functional.

Starting with the $18^{\text {th }}$ century, as science, culture, and arts underwent rapid development, the national self-awareness of Ukrainians grew, too, triggering with it certain changes in the "external core of language". Thus, for instance, people started pronouncing $\boldsymbol{r}$ as [i]; [o] became [y] in many instances and [e] transitioned into [i]. In the written language, people started confusing $u \mathrm{i}$ and $b l$ both denoting the same sound, corresponding to Latin $y$ in Western Slavic 
languages (Farion, 2005: 20-21). The Ukrainian grapheme system became more and more unique, increasingly diverging from the grapheme systems of other Slavic language cultures. There is ample evidence of the fact that this very period is marked by a distinctive impact of Ukrainian linguography upon the Russian linguography - partially in view of a specific manner of usage of the letter $r$. Ukrainians had then hoped that their system of writing would become more entrenched; in 1708, however, Russian Emperor Peter I banned the usage of Cyrillic (with its graphemes) and mandated the introduction of the so-called grazhdanka or "Civil Script' - which was more adapted to the needs and peculiarities of Russian and not Ukrainian. So began the oppression of the Ukrainian linguistic culture. Traditional Cyrillic script was only permitted when and if one intended to publish Church Slavonic texts. Diacritics went into disuse; the letter $t / g$ was abolished, Western Arabic numerals were introduced instead of Old Slavonic numerals (Ohiienko, 1990: 4). In addition to that, the letters $\omega$ (omega), $\psi$ (psi), v (izhytsia), ж (the Big yus) and $x$ (the Little yus) also went into disuse; the letter $\epsilon$ (ye) came to be used instead of $\iota \epsilon$; the letter $g$ instead of $\imath a$. That said, certain other letters such as $\theta$ (fita) and $r$ (yat) which were doubling for similar sounds remained in the alphabet.

In the year 1720, Emperor Peter I introduced a ban on printing Church literature in the Ukrainian language (Ohiienko, 1990: 5) - which, of course, slowed down the progress in the development of Ukrainian linguography (as well as the development of its graphics and orthography) and which was accordingly detrimental to the Ukrainian linguistic culture, by and large.

In the $18^{\text {th }}$ and the $19^{\text {th }}$ centuries, neither the Ukrainian East nor its West had a unified standard in place stipulating rules for Ukrainian civil script, alphabet, or spelling. Cultural activists who were interested in the development of the Ukrainian language, writers and academic researchers were experimenting, each of them putting an effort into the enhancement of the spelling, striving for their spelling to correspond to the norms of the Ukrainian language as much as was possible.

The first impressions (pressworks) of the civil script were produced in the town of Zhovkva (now in Lviv oblast). That script gained popularity in the Ukraine-upon-the-Dnipro (which was then part of the Russian Empire) and then also in the Ukrainian West (Lopushynskii, 2009: 36). Notwithstanding the apparently oppressive measures taken by the government and the church with respect to the Ukrainian language, its development in the said period is clearly marked by new achievements and social phenomena. It was marked by growth in selfawareness with respect to the wide range of social functions the language was to fulfil (particularly the nation-building function and essence of the language) and reinforced the idea of necessity and inevitability of defence of language and national rights of the Ukrainian nation" (Boriiak, 2007: 41-42) and this, in turn, was reflected in the development of Ukrainian linguography, too.

Despite the oppressions and bans, Oleksii Pavlovskyi put together a new set of Ukrainian spelling rules. He was able to "liberate" the living language from the "Old Slavonic Russianstyle shackles". In particular, he introduced the graphic denotation for the phoneme [i] which was henceforth to be represented as just $i$ in writing; $r o$ was thenceforth used to denote [je]; the diphtong [io] denoted the sound [jo] (Farion, 2005: 23-24). Let us also recall the fact that Eneida by Ivan Kotliarevskyi prompted "the shaping of a brand new model used to register the folk, people's language in belles-lettres literature, first and foremost" (Boriiak, 2007: 41-42). As Iryna Farion emphasises, Markiian Shashkevych also contributed to the development of Cyrillic script, as he introduced the Church Slavonic $\epsilon / y e$, abolished $b$ (the hard sign) which was deemed to be redundant, substituted $b l$ with $u$; and started using $i$ to convey [o] and [e]. Galicians were reluctant to accept these novelties, but the residents of the "Great Ukraine" accepted it thanks to the active promotion by Levko Borovykovskyi (Farion, 2005: 25-26). The Ukrainian almanac entitled "Русалка Дныстровая" (Rusalka Dnistrovaya, "the Dnister Mermaid") also introduced timely changes in the Ukrainian orthography, specifically: the soft consonants before $\boldsymbol{o}$ was reflected by the usage of the soft sign, $\boldsymbol{b}$, and the iotisation was reflected by resorting to $\check{\boldsymbol{u}}$ : Кроуццьоў груди обкипгли/Krowtsiow hrudy obkyp(y)ily; Заточиу ся під Мадейом Кін[b] на колодище/Zatochyw sia pid Madeiom Kin(y) na kolodyshche; По під гайом зелененьким Чиста рючка тече/Ро pid haiom zelenen(y)kym Chysta r(y)ichka teche" (Nimchuk, 2004: 7). Markian Shashkevych was an advocate of the folk language and endorsed the introduction of phonetic spelling which was to replace the traditional, etymology-based spelling. This struggle had lasted for a certain period of time, this "democratization" of the literary language was viewed by both Poland and Russia as a phenomenon contributing to the weakening of the positions of Polish and Russian language, and hence to the weakening of the influence exerted by corresponding countries. Besides, rulers of both Russia and Poland considered the language of the 
Ukrainian nation to be a "dialect component" of their respective languages (a position entertained in Russia even nowadays). In the opinion of Zynoviia Franko, the activities of the representatives of the "Ruska Triitsia/Ruthenian Triad" who were guided by and provided support to the living, popular language as an "attribute of national self-expression and national self-preservation" (Franko,1990: 11-22) constituted that crucial factor which stood against Russian and Polish encroachments. This was widely reflected in the language biography of Ukraine (Kosmeda, 2015) wherein the specifics of the development of Ukrainian linguistic culture are consistently describes as the consequence of oppression from both ends: from Russian and from Polish language cultures.

The development of the Ukrainian graphics and orthography was actively assisted by Mykhailo Drahomanov who subscribed to the opinion that usage of a single character to denote iotated vowels (which are actually comprised of two sounds) is slightly inconvenient and not very practical. In 1877, Drahomanov switched to using a single letter to denote each separate sound in his works. Specifically, he introduced $\boldsymbol{j}$ to convey the apostrophe in writing, (мjaco/mjaso/myaso); he also replaced $\check{\boldsymbol{u}}$ with $\boldsymbol{j}$ in words like daje/daye, моју/mоуи, јама/уата. He also used two letters, $\boldsymbol{\mu} \boldsymbol{u} / \mathrm{shch}$ instead of a single letter $\boldsymbol{\boldsymbol { \mu }}$. This alphabet system was dubbed Drahomanivka in his honour. Galicia followed the rest of Ukraine in using this alphabet, one notable adopter being Ivan Franko who used it in his works (Ohiienko, 2010: 343-344).

Another prominent reformer of the Ukrainian spelling was Panteleimon Kulish. His spelling system as rightly noted by Vasyl Simovych could "use the most basic, least sophisticated characters to denote the sounds of the Ukrainian language" (Simovych, 2005: 337). Vasyl Simovych asserts that the greatest achievement of Panteleimon Kulish consists, first and foremost, in the fact that "characters used thereby were already an evidence of the fact that one was thus dealing with a separate, unique, independent language" (Simovych, 2005: 337). Initially, Panteleimon Kulish was using the "Maksymovychivka" system (with a hard sign, $\boldsymbol{n} \boldsymbol{s}$, and circumflex above $\boldsymbol{o}, \boldsymbol{e}, \boldsymbol{u}, \boldsymbol{y}$, and $\boldsymbol{a}$ ), as he was convinced at the beginning that his own spelling system was "in contravention of the national tradition" (Simovych, 2005: 338). He only addressed his Kulishivka in 1856 for the first time: thus, we observe the usage of $\boldsymbol{n} \boldsymbol{b}, \ddot{e}$, Latin g, Church Slavonic $\boldsymbol{\theta}$, etc. (Simovych, 2005: 339). The editor had put effort into making sure "words do not lose their fabric, so that when certain sounds come together in one's pronunciation, one sound impacting the other, some of these sounds might otherwise be replaced or assimilated to the other one" (Simovych, 2005: 339). Thus, from the year 1882, Kulishivka was phoneticsbased (Simovych, 2005: 339-340).

In the opinion of Ivan Ohiyenko, however, Kulishivka had in fact not introduced anything new, and had only "made popular" those most successful features that had already been present in preceding spelling systems (Ohiienko, 1990: 8). Panteleimon Kulish was inconsistent in his approach to spelling and modified it several times. Initially, he stuck to the etymological (that is, historically entrenched) principle; then, he switched to the phonetic based approach. Panteleimon Kulish's activity, however, was undeniably beneficial to the development of Ukrainian linguography, graphics, and orthography, as Kulish contributed to its progress, establishment, and reinforcement - particularly considering the circumstances in which he was forced to work - as Oleksandr Danylenko asserts, quite convincingly.

Volodymyr Antonovych, Mykhailo Drahomanov, Pavlo Zhytetskyi, Mykola Lysenko, Kostiantyn Mykhalchuk, Pavlo Chubynskyi eventually improved Kulishivka by introducing and implementing certain modifications: $\ddot{i}$ came to denote an iotated sound [i]; $\epsilon$ came to denote an iotated [e]; $b$ at the end of the word was abolished; $\kappa 2$ (instead of $g$ ) was rendering the letter $t$ in writing (Farion, 2005: 27).

In 1863, the Valuev Decree (circular) was published and came into force. The decree was sanctioned by Russian Emperor Alexander II and was banning the use of Ukrainian language for religious and educational books across the Russian Empire. Ukrainian writers were only able to get their books printed across the border, in Galicia. This, however, turned out to be not enough for the imperial appetite of Russia, and so, on the $30^{\text {th }}$ of May, 1876, Tsar (Emperor) Alexander II signed yet another decree, altogether banning any printed texts in Ukrainian language (the Ems Ukase). This new ban covered any kind of literature whatsoever (apart from certain historical documents and belleslettres texts, the latter being subject to scrupulous censorship and only allowed if printed in the Russian transliteration). There is evidence of the fact that, due to the presence of the letter $\boldsymbol{i}$ used in place of $\boldsymbol{u}$, a collection of songs by Mykola Lysenko could not be printed. This ukase forced Ukrainians to look for a way out of this quandary: say, Borys Hrinchenko, working as a teacher, was rewriting dozens of books for his students, copying them by hand off the printed copy he had.

The aforementioned bans inflicted terrible pain upon the entire development of Ukrainian culture, language, and literature. This last ban was in effect for the ensuing 30 years or so (until the Revolution 
of 1905) (Vaskovych, 1976: 3-4). Ukrainian intelligentsia ironically dubbed this decree "yaryzhka" due to the name of letter $\boldsymbol{b l}$ (which had traditionally been referred to as yery) (Farion, 2005: 27).

Then, in 1907, partial ban on Ukrainian printed literature was reintroduced; this ban was reinforced in 1914 and was only abolished in 1917. By and large, the ban on printing texts in the Ukrainian language was in place for 55 years in total. This ban had hindered the development of Ukrainian linguistic culture, although the Ukrainian people were highly inventive in circumventing and resisting this disgraceful law.

Notwithstanding the fact that the abovementioned edicts and decrees of the Russian Empire were indeed hindering the development of Ukrainian linguography, as a result of the linguistic creative activity of the Ukrainian nation, its meta-language was also enriched by those elements of the system of images that pertained to the ban on printing of works in the Ukrainian language and to its reform - and today, these elements (terms) constitute the corpus of its terminology.

It was not just the Russification, though, that was slowing down the cultural development of Ukrainian printing and publishing business, graphics, and orthography in particular, as well as of Ukraine as a whole. There was also the Latinisation dating back to the early $17^{\text {th }}$ century, when the Latin language was used not only by ecclesiastical figures but by certain writers, too. In the $17^{\text {th }}$ and the $18^{\text {th }}$ centuries, creative activity in the Latin language became widespread in Ukraine. Latin was used by both professors and alumni of the Kyiv-Mohyla Academy. Eventually, the Austrian Empire made attempts to latinise the Galician Ukrainian written language system, too. The "Ukrainian Latin alphabet" was to be constructed on the basis of Czech that is, diacritics and sound meanings for certain letters were to be derived from the Czech alphabet. This presented another challenge to the development of Ukrainian linguistic culture that was striving to develop a graphical system for its language, for its linguography.

Thus, in 1859, Josef Jireček published a book in Vienna, entitled Ueber den Vorschlag, das Ruthenische mit lateinischen Schriftzeichen zu schreiben ("On the Proposal to start writing Ukrainian with Latin Characters"), wherein he asserted that both the Ukrainian grammar and its phonetics are not developed sufficiently for the writing system to be in order, hence he suggested that Ukrainians opt for the Latin alphabet (Moiseienko). In the opinion of Vasyl Simovych, "Jireček's Latin alphabet is a combined/ mixed product of creation" which was to include those Latin letters that are being pronounced similarly in all systems of Slavic languages, specifically: $\boldsymbol{a}, \boldsymbol{e}$, $i, o, u, p, b, m, f, t, d, s, z, c, r, n, l, k, g, c h, j$. Most of the orthographic principles were thereby derived from Czech, and some of them also from Polish (Simovych, 2005: 98-99). Again, we are dealing with a brutal intrusion into the development of the system of Ukrainian graphics, linguography, and linguistic culture as a whole.

Let us here concur with Iryna Farion who asserts that one achievement of Galicians and Bukovinians, in their clashes on the matter of spelling and writing systems, was the Austrian decree permitting the usage of the Ruthenian Grammar, a textbook on orthography put together by Stepan Smal-Stotskyi and Theodor Gartner (Farion, 2005: 28-29). This textbook was based on the phonetic orthography of Yevhen Zhelekhivskyi - the so-called zhelekhivka whereby the letter $\ddot{i}$ was transformed from $\breve{u}+i$ to $b l$, and the letter $\epsilon$ was transformed from $\breve{u} e$ to be. They acquired the same characteristics and fulfilled the same functions as did letters $я / \mathrm{ya}, ю / \mathrm{yu} ; \mathrm{u} / \mathrm{ts}, 3 / \mathrm{z}$, $c / s$ as they get softened when standing before labial consonants $\ddot{1} / \mathrm{yi}, \quad$ a/ya $3 / \mathrm{z}$ b/soft sign (Simovych, 2005: 195). Yevhen Zhelekhivskyi was also promoting the usage of the apostrophe and introduced the distinction between $\check{u} о$ and ьо; he did, however, leave $i$ to denote an iotated [i] and removed the soft sign, $b$, from certain words (сьвіт->світ, цьвіт $>$ uвim) (Simovych, 2005: 220).

Issues related to teaching Ukrainian script in Galicia, availability of textbooks, ABC books based on corresponding principles of graphemics have been examined in Prychynky do Istoriyi Ukrayinskoyi Movy/(Contributions to the history of the Ukrainian language) a book by Austrian linguist, Michael Moser, who uncovered the content and the form of Galician ABC books which were used by village kids "to imagine how their mother tongue should have looked like in writing, as prescribed by leading Galician language activists" (Mozer, 2008: 392).

Conclusions. As we can see, the activity pursued by Ukrainian academic researchers contributed to the improvement of Ukrainian graphics and orthography, boosted the establishment of Ukrainian linguography by shaping its meta-language in a peculiar fashion. Having introducing such notions and image-based terms as Drahomanivka, Zhelekhivka, Kulishivka, Maksymovychivka etc., the Ukrainian people have also invented a metaphor used to denote disapproval of a certain phenomenon, yaryzhka, which was imprinted in the memory of Ukrainian native speakers as a highly negative piece of experience. The development and progress of Ukrainian graphics and orthography, graphemics and linguography was hindered by bans imposed upon printing of texts in the Ukrainian language; 
by attempts to forcefully introduce foreign linguographic traditions, and also by striving to modify the Ukrainian alphabet and its graphic system so drastically that it would be beyond recognition. This included attempts to purge certain letters but also to replace the alphabet entirely, by switching from Cyrillic to Latin.

\section{BIBLIOGRAPHY}

1. Булаховський Л. А. Розвиток української літературної мови. Вибр. праці : в 5 томах . Т. 2. Українська мова. Київ : Наук. думка, 1977. 631 с.

2. Бурячок А. А. Що змінилося в «Українському правописі»? Київ : Наук. думка, 1997. 52 с.

3. Васькович Г. Емський указ і боротьба за українську школу. Мюнхен : Кооперат. друк. «Ціцеро», 1976. 20 с.

4. Вихованець I. Р. Ненаукові пристрасті навколо українського правопису. Українська мова. 2004. № 2. С. 3-24.

5. Гриценко Т. Б. Українська мова за професійним спрямуванням : навч. посіб. Київ : Центр учб. літ., 2010.624 с.

6. Данильчук Д. В. Український правопис: роздоріжжя і дороговкази : монографія. Київ : Либідь, 2013. 224 с.

7. Дорошенко С. І. Чинний «Український правопис» потребує допрацювання. Наукові простори : вибр. пр. Харків : Нове слово, 2009. С. 228-229.

8. Дорошенко С. І. Ще раз про нову редакцію «Українського правопису». Наукові простори : вибр. пр. Харків : Нове слово, 2009. С. 229-235.

9. Єрмоленко С. Я. Думки про український правопис. Культура слова. 1993. Вип. 44. С. 3-9.

10. Срмоленко С. Я. Зміни закономірні, поступові, але не революційні. Мовознавство. 1995. № 1. С. 32-34.

11. Космеда Т. А. Вектор формування нових мовних і комунікативних норм в українському дискурсивному просторі. Лінгвістичні дослідження : збірник наукових праць Харківського начіонального педагогічного університету імені Г. С. Сковороди / гол. ред. проф. К. Ю. Голобородько. Харків, 2016. Вип. 43. С. $42-50$.

12. Космеда Т. А., Осіпова Т. Ф., Піддубна Н. В. Степан Руданський: феномен моделювання «живого» мовлення українців. Харків-Познань-Дрогобич : Коло, 2015. 312 с.

13. Лопушинський І. П. Повернення до історичної графіки української мови : нагальна державна і наукова проблема чи чергова забаганка політиків? (у порядку дискусії до 300-річчя «Гражданки»). Науковий вісник Херсонського державного університу. Серія : «Лінгвістика» : зб. наук. пр. / гол. ред. В. Олексенко. 2009. Вип. IX. С. $29-37$.

14. Мозер М. Причинки до історії української мови / за заг. ред. С. Вакуленка. Харків : Харків. істор.-філол. тов-во, 2008. $832 \mathrm{c.}$

15. Мойсеєнко В. Про одну спробу латинізації українського письма. Незалежний культурологічний часопис «Ї». URL: http://www.ji.lviv.ua/n9texts/mojsejenko.htm (дата звернення: 20.12.21).

16. Німчук В. В. Дещо про графіку та правопис як елементи етнічної культури: історія г. Мовознавство. 1991. № 1. C. 9-18.

17. Німчук В. В. Переднє слово. Історія українського правопису : XVI-XX століття : хрест. / уп. В. В. Німчук. Київ : Наук. думка, 2004. 584 с.

18. Огієнко I. Нариси з історії української мови : система українського правопису. Вінніпег, 1990. 216 с.

19. Огієнко І. Рідна мова / упоряд., авт. передмови та коментарів М. С. Тимошик. Київ : Наша культура і наука, 2010. $436 \mathrm{c}$.

20. Сімович В. В. Йосиф Їречек і українська мова. Праці у двох томах. Т. 1. : Мовознавство. Чернівці : Книги XXI, 2005. C. 73-122.

21. Сімович В. В. Кулішева мова й «кулішівка». Праці : у двох томах. Т. 1. : Мовознавство. Чернівці : Книги XXI, 2005. C. 336-341.

22. Сімович В. В. Літери і політика. Праці : у двох томах. Т. 1. : Мовознавство. Чернівці : Книги - XXI, 2005. C. $216-223$.

23. Сімович В. В. Українська мова і правопис. Праці : у двох томах. Т. 1. : Мовознавство. Чернівці : Книги - XXI, 2005. C. 181-197.

24. Степаненко М. І. Історія українського орфографічного кодексу й сучасні правописні дискусії. Вивчаємо українську мову та літературу : науково-методичний журнал. 2010. № 7. С. 9-12.

25. Українська ідентичність і мовне питання в Російській імперії: спроба державного регулювання / упоряд. Г. Боряк. Київ : ТОВ Вид-во «Кліо», 2007. 808 с.

26. Фаріон І. Д. Мовна краса і сила : Суспільно-креативна роль української мови в XI - середині XIX ст. 4-те вид.

Львів : Вид-во Львів. політех., 2011. 212 с.

27. Фаріон I. Д. Правопис - корсет мови? (Український правопис як культурно-історичний вибір). Львів : Свічадо, 2005. $120 \mathrm{c}$.

28. Фіголь Н. М. Сучасні правописні дискусії. Актуальні проблеми української лінгвістики : теорія і практика.

2011. Вип. 22. С. 91-95.

29. Франко 3. Т. Боротьба за українську мову в дожовтневий період. Мовознавство. 1990. № 6. С. 11-17.

30. Шевельов Ю. В. О. О. Потебня і стандарт української літературної мови. Вибр. пр. : у 2 кн. Кн. І : Мовознавство / упоряд. Л. Масенко. Київ : Вид-ий Дім «Києво-Могилян. Акад.», 2009. 583 с.

\section{REFERENCES}

1. Bulakhovsjkyj L. A. Rozvytok ukrajinsjkoji literaturnoji movy. Vybr. praci : v 5 tomakh [Development of the Ukrainian literary language. Works in 5 volumes.]. Vol. 2.Ukrajinsjka mova [Ukrainian language]. Kyjiv: Nauk. dumka, 1977. 631 p. [in Ukrainian].

2. Burjachok A. A. Shho zminylosja v «Ukrajinsjkomu pravopysi»? [What has changed in "Ukrainian spelling”]. Kyjiv : Nauk. dumka, 1997. 52 p. [in Ukrainian]. 
3. Vasjkovych Gh. Emsjkyj ukaz i borotjba za ukrajinsjku shkolu [Ems decree and the struggle for the Ukrainian school]. Mjunkhen : Kooperat. druk. "Cicero", 1976. 20 p. [in Ukrainian].

4. Vykhovanecj I. R. Nenaukovi prystrasti navkolo ukrajinsjkogho pravopysu [Non-scientific passions around Ukrainian spelling]. Ukrajinsjka mova [Ukrainian language]. 2004. № 2. pp. 3-24. [in Ukrainian].

5. Ghrycenko T. B. Ukrajinsjka mova za profesijnym sprjamuvannjam : navch. posib. [Ukrainian language for professional purposes: a textbook]. Kyjiv: Centr uchb. lit., 2010. 624 p. [in Ukrainian].

6. Danyljchuk D. V. Ukrajinsjkyj pravopys : rozdorizhzhja i doroghovkazy : monoghrafija [Ukrainian spelling: crossroads and signposts: monograph]. Kyjiv: Lybidj, 2013. 224 p. [in Ukrainian].

7. Doroshenko S. I. Chynnyj «Ukrajinsjkyj pravopys» potrebuje dopracjuvannja [The current "Ukrainian spelling" needs to be improved]. Naukovi prostory : vybr. pr. [Scientific spaces: selected works]. Kharkiv: Nove slovo, 2009. pp. 228-229. [in Ukrainian].

8. Doroshenko S. I. Shhe raz pro novu redakciju «Ukrajinsjkogho pravopysu» [Once again about the new edition of "Ukrainian spelling"]. Naukovi prostory : vybr. pr. [Scientific spaces: selected works]. Kharkiv: Nove slovo, 2009. pp. 229-235. [in Ukrainian].

9. Jermolenko S. Ja. Dumky pro ukrajinsjkyj pravopys [Thoughts on Ukrainian spelling]. Kuljtura slova [The culture of the word]. 1993. Vol. 44. pp. 3-9. [in Ukrainian].

10. Jermolenko S. Ja. Zminy zakonomirni, postupovi, ale ne revoljucijni [Changes are natural, gradual, but not revolutionary]. Movoznavstvo [Linguistics]. 1995. № 1. pp. 32-34. [in Ukrainian].

11.Kosmeda T. A. Vektor formuvannja novykh movnykh i komunikatyvnykh norm v ukrajinsjkomu dyskursyvnomu prostori [Vector of formation of new language and communicative norms in the Ukrainian discursive space]. Linghvistychni doslidzhennja : zb. nauk. pr. [Linguistic research: a collection of scientific papers]. Kharkiv. nac. ped. un-tu im. Gh. S. Skovorody / ghol. red. prof. K. Ju. Gholoborodjko. Kharkiv, 2016. Vol. 43. pp. 42-50. [in Ukrainian].

12. Kosmeda T. A., Osipova T. F., Piddubna N. V. Stepan Rudansjkyj : fenomen modeljuvannja «zhyvogho» movlennja ukrajinciv [Stepan Rudansky: the phenomenon of modeling the "living" speech of Ukrainians]. Kharkiv-Poznanj-Droghobych: Kolo, 2015. 312 p. [in Ukrainian].

13. Lopushynsjkyj I. P. Povernennja do istorychnoji ghrafiky ukrajinsjkoji movy : naghaljna derzhavna i naukova problema chy cherghova zabaghanka politykiv? (u porjadku dyskusiji do 300-richchja «Ghrazhdanky») [Return to the historical graphics of the Ukrainian language: an urgent state and scientific problem or another whim of politicians? (in the order of discussion to the 300th anniversary of "Ghrazhdanky")]. Nauk. visn. Kherson. derzh. un-tu. Ser. : «Linghvistyka» : zb. nauk. pr. [Scientific Bulletin of Kherson. state un-tu. Series: "Linguistics": a collection of scientific papers] / ghol. red. V. Oleksenko. 2009. Vol. IX. pp. $29-37$. [in Ukrainian].

14. Mozer M. Prychynky do istoriji ukrajinsjkoji movy [Reasons for the history of the Ukrainian language] / za zagh. red. S. Vakulenka. Kharkiv: Kharkiv. istor.-filol. tov-vo, 2008. 832 p. [in Ukrainian].

15. Mojsejenko V. Pro odnu sprobu latynizaciji ukrajinsjkogho pysjma [About one attempt to Latinize the Ukrainian alphabet]. Nezalezhnyj kuljturologhichnyj chasopys «Ji» [Independent culturological magazine "Yi”]. Retrieved from: http://www.ji.lviv.ua/ n9texts/mojsejenko.htm [in Ukrainian].

16. Nimchuk V. V. Deshho pro ghrafiku ta pravopys jak elementy etnichnoji kuljtury: istorija g [Something about graphics and spelling as elements of ethnic culture: history of g]. Movoznavstvo [Linguistics]. 1991. № 1. pp. 9-18. [in Ukrainian].

17. Nimchuk V. V. Perednje slovo. Istorija ukrajinsjkogho pravopysu : XVI-XX stolittja : khrest. [Foreword. History of Ukrainian spelling: XVI - XX centuries: textbook] / up. V. V. Nimchuk. Kyjiv: Nauk. dumka, 2004. 584 p. [in Ukrainian].

18. Oghijenko I. Narysy z istoriji ukrajinsjkoji movy : systema ukrajinsjkogho pravopysu [Essays on the history of the Ukrainian language: the system of Ukrainian spelling]. Vinnipegh, 1990. 216 p. [in Ukrainian].

19. Oghijenko I. Ridna mova [Native language] / uporjad., avt. peredmovy ta komentariv M. S. Tymoshyk. Kyjiv: Nasha kuljtura i nauka, 2010. 436 p. [in Ukrainian].

20. Simovych V. V. Josyf Jirechek i ukrajinsjka mova. Praci u dvokh tomakh [Joseph Irechek and the Ukrainian language. Works in two volumes]. Vol 1. : Movoznavstvo [Linguistics]. Chernivci: Knyghy - XXI, 2005. pp. 73-122. [in Ukrainian].

21. Simovych V. V. Kulisheva mova j «kulishivka» Praci u dvokh tomakh [Kulish’s language. Works in two volumes]. Vol. 1. : Movoznavstvo [Linguistics]. Chernivci: Knyghy - XXI, 2005. pp. 336-341. [in Ukrainian].

22. Simovych V. V. Litery i polityka. Praci u dvokh tomakh [Letters and politics. Works in two volumes]. Vol 1. : Movoznavstvo [Linguistics]. Chernivci : Knyghy - XXI, 2005. pp. 216-223. [in Ukrainian].

23. Simovych V. V. Ukrajinsjka mova i pravopys Praci u dvokh tomakh [Ukrainian language and spelling. Works in two volumes]. Vol 1. : Movoznavstvo [Linguistics]. Chernivci: Knyghy - XXI, 2005. pp. 181-197. [in Ukrainian].

24. Stepanenko M. I. Istorija ukrajinsjkogho orfoghrafichnogho kodeksu j suchasni pravopysni dyskusiji [History of the Ukrainian orthographic code and modern spelling discussions]. Vyvchajemo ukr. movu ta lit. : nauk. metod. zhurnal [We study Ukrainian. language and literature: science. method. magazine]. 2010. № 7. pp. 9-12. [in Ukrainian].

25. Ukrajinsjka identychnistj i movne pytannja v Rosijsjkij imperiji : sproba derzhavnogho reghuljuvannja [Ukrainian identity and the language issue in the Russian Empire: an attempt at state regulation] / uporjad. Gh. Borjak. Kyjiv: TOV Vyd-vo "Klio", 2007. 808 p. [in Ukrainian].

26. Farion I. D. Movna krasa i syla : Suspiljno-kreatyvna rolj ukrajinsjkoji movy v XI - seredyni XIX st. [Linguistic beauty and power: Socio-creative role of the Ukrainian language in the XI - mid XIX centuries] 4-te vyd. Ljviv: Vyd-vo Ljviv. politekh., 2011. 212 p. [in Ukrainian].

27. Farion I. D. Pravopys - korset movy? (Ukrajinsjkyj pravopys jak kuljturno-istorychnyj vybir) [Spelling - a corset of language? (Ukrainian spelling as a cultural and historical choice)]. Ljviv: Svichado, 2005. 120 p. [in Ukrainian].

28. Figholj N. M. Suchasni pravopysni dyskusiji [Modern spelling discussions]. Aktualjni problemy ukrajinsjkoji linghvistyky : teorija i praktyka [Current issues of Ukrainian linguistics: theory and practice]. 2011. Vol. 22. pp. 91-95. [in Ukrainian].

29. Franko Z. T. Borotjba za ukrajinsjku movu v dozhovtnevyj period [The struggle for the Ukrainian language in the preOctober period]. Movoznavstvo [Linguistics]. 1990. № 6. pp. 11-17. [in Ukrainian].

30. Sheveljov Ju. V. O. O. Potebnja i standart ukrajinsjkoji literaturnoji movy [O. O. Potebnya and the standard of the Ukrainian literary language]. Vybr. pr. : u 2 kn. Kn. I : Movoznavstvo [Selected works: in 2 books. Book I: Linguistics]/ uporjad. L. Masenko. Kyjiv: Vyd-yj Dim “Kyjevo-Moghyljan. Akad.”, 2009. 583 p. [in Ukrainian]. 